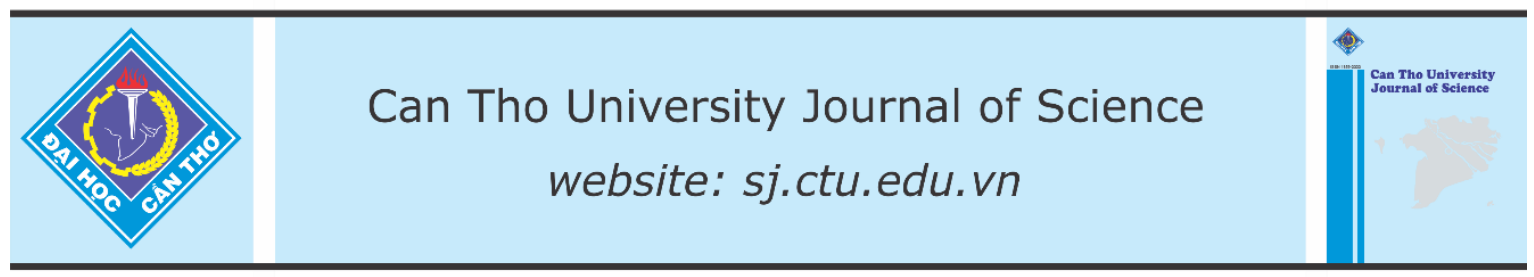

DOI: 10.22144/ctu.jen.2020.022

\title{
Impacts of a one-shot training program for in-service teachers on the application of Task-based Language Teaching
}

Nguyen Anh Thi ${ }^{*}$ and Phuong Hoang Yen

School of Foreign Languages, Can Tho University, Vietnam

*Correspondence: Nguyen Anh Thi (email: nathi@ctu.edu.vn)

\section{Article info.}

Received 21 Jun 2020

Revised 08 Aug 2020

Accepted 30 Nov 2020

\section{Keywords}

Classroom practice, in-service teacher training, Taskbased language teaching

\begin{abstract}
Task-based language teaching (TBLT) has been recently implemented as a potential language teaching method for language education in Vietnam. However, research into the training for teachers on the application of TBLT has remained scarce. This study, therefore, aims to examine how Vietnamese in-service teachers implement the insights from a one-shot training program on TBLT in their classroom-based teaching practices. Three in-service teachers at a university in Vietnam participated. Data were collected through a video-taped classroom observation activity. The findings indicate that the teachers on the whole were unable to transfer the theoretical knowledge of TBLT principles that they had built up during the training program into their actual teaching practices. In addition, the teachers failed to perform TBLT teaching roles throughout the lesson. Accordingly, this study suggests pedagogical implications and insights with regard to the issue of teacher training on TBLT in the context of language education in Vietnam.
\end{abstract}

Cited as: Thi, N.A. and Yen, P.H., 2020. Impacts of a one-shot training program for in-service teachers on the application of Task-based Language Teaching. Can Tho University Journal of Science. 12(3): $38-46$.

\section{INTRODUCTION}

The early years of the $21^{\text {st }}$ century has marked a tremendous shift in (foreign) language education in Vietnam. Due to the long-term dominance of traditional teaching curriculum and methods which primarily place a strong focus on form-based instruction and teacher-centered education which might hinder learners' opportunities to acquire the language effectively, the Vietnamese educational leaders, therefore, took action implementing a number of innovations in language education including methodological innovations on the one hand, and on the other hand, teacher training on how to apply them in practical classrooms.

For one, for instance, as proposed by the Ministry of Education and Training (MoET) in 2004, the Presentation-Practice-Production (PPP) method was officially introduced into the language teaching curriculum in Vietnam. This is because this method was believed to have greater impact on learners' language development than traditional methods: PPP reflected a notion of practice makes perfect, which is common in many skills (Thornbury, 1999) and it provided a clear role for the teacher, which is in accordance with power relations often found in Asian classrooms (Skehan, 2003). 
However, it should be noticed that PPP to date has been criticized by many scholars and researchers (Skehan, 2003; Ellis and Shintani, 2014) due to its negative impacts on language education. Therefore, poor outcomes in English proficiency among Vietnamese learners have still remained considerable concerns for both educational policy-makers and language teachers.

For another, a new English language teaching curriculum proposed by the MoET was introduced in 2006. This curriculum placed a great focus on the promotion of Communicative Language Teaching (CLT) and TBLT, stating that, "communicative skills are the goal of the teaching of English at the secondary school while formal knowledge of the language serves as the means to an end", "learnercentered, communicative task-based" language teaching must be a priority (MoET, 2006, p. 14).

In accordance with the introduction of PPP, CLT, and TBLT, training teachers toward the use of those mentioned methods has been taken into consideration since the past decade. However, it is worth mentioning that currently in Vietnam, most of the training programs for in-service teachers often take place in the form of a typical single-shot workshop which mainly consists of theoretical background and discussion of basic principles (Canh, 2011). There is a vast research-based literature on the impact of this kind of in-service training on teachers' professional development, amply showing that it has only very limited impact (Van den Branden, 2006). In an attempt to check whether this kind of restricted training actually has any effects on Vietnamese teachers, we conducted a study investigating how in-service teachers, who have been using traditional formbased approaches for years, implemented the insights from a one-shot training program on TBLT into their teaching practices. Based on these explorations, recommendations for enhancing the opportunity for TBLT implementation as well as improving the quality of the innovation program will be suggested.

\section{LITERATURE REVIEW}

\subsection{Task definitions}

Over the past decades, different definitions of task have been proposed (Long, 1985; Richards, Platt \& Weber, 1985; Breen, 1987; Nunan, 1989; Caroll, 1993; Bachman \& Palmer, 1996; Bygate, Skehan \& Swain, 2001; Van den Branden, 2006). In general, definitions of task fall into two categories.
Firstly, task is considered the main unit for defining language learning goals. In this view, task involves everyday activities, pieces of work or job responsibilities that intentionally focus on goals that need to be achieved (Long, 1985). Van den Branden (2006, p.4) defines a language task as "an activity in which a person engages in order to attain an objective, and which necessitates the use of language".

Secondly, task is also conceptualized as the main unit of analysis for organizing educational activities. In this respect, the kind of tasks used in the classroom (classroom tasks) should be closely related to, or derived from what the learners are actually supposed to do (target tasks) in the real world (Van den Branden, 2006). In this respect, placing a strong focus on meaning should be a priority and the classroom task needs to offer learners an opportunity to work with meaningful input, and promote interaction among learners (Nunan, 1989).

\subsection{Key principles of Task-based language teaching}

TBLT has been widely used around the world. TBLT has attempted to combine the needs for pedagogic and naturalistic learning processes in language teaching and learning (Skehan, 1996).

\subsubsection{Holistic teaching and learning}

According to Van den Branden, Bygate and Norris (2009, p.2), the learners are expected to "induce knowledge about smaller units from their actual performances and communication challenges in complex situations". In this respect, learners are fully supported and encouraged to work with real-life tasks and engage in intensive interaction, and as a result, they are claimed to learn the target language more effectively (Long, 2015). In accordance with this, TBLT is said it does not chop up the language into smaller pieces, but takes holistic, functional and communicative tasks as its main unit of analysis (Van den Branden, 2006).

\subsubsection{Learner-centered approach}

Another prominent characteristic of TBLT is learner-centered education (Ellis, 2003; Van den Branden, 2006, 2016; Van den Branden et al., 2009; Ellis \& Shintani, 2014; Long, 2015). The learners are encouraged to engage in communicative activities and reflect on what they are learning. They should be motivated and made responsible for taking care of their own learning process. In TBLT, the 
teacher and learners are joint decision-makers in all classroom activity.

\subsubsection{Meaning-based focus}

TBLT primarily places a strong focus on meaning, regarding communicative effectiveness in realworld tasks as the main concern, stating that communication must be the center of all pedagogical activities and teaching procedures (Van den Branden et al., 2009). Long (2015) argues that second language learners need to be provided with functional tasks and have to be involved in intensive interaction and real-world language use. In the same vein, Van den Branden (2016) states that learners need to be exposed to meaningful input from the very early stages of second language acquisition. By focusing on meaning rather than linguistic accuracy while communicating and interacting with their interlocutors, learners' motivation and interest can be successfully promoted.

\subsubsection{Form-based focus}

Despite TBLT places a strong focus on meaning, it does not preclude form-focused activities. In other words, it integrates form-focused activities (Ellis, 2009; Ellis \& Shintani, 2014; Norris, 2016; Van den Branden et al., 2009; Van den Branden, 2016). It is said that TBLT "allows, even encourages - a focus on form in view of optimizing the learning potential of task-based educational activities" (Van den Branden et al., 2009, p. 6). As such, explicit formfocused instruction can be considered an integral part of TBLT (Van den Branden, 2016). The term focus on forms, in a TBLT perspective, refers to the teaching of linguistic items within the context of communicative activities. This typically occurs when the teacher reacts to the form-focused issues that learners are struggling with during the performance of communicative tasks. For instance, during the negotiation for meaning such as asking for clarification, rephrasing, or confirming given information (Long, 2015), the learner(s) can be supported by the teacher and other learners to deal with new linguistic items without interrupting the flow of the communication. Van den Branden (2016) advocates that the teacher may also correct learners' errors or scaffold their problem-solving in an explicit way to help them figure out problems while understanding or producing an utterance. In fact, focusing on forms helps increase learners' language proficiency and accuracy (Ellis \& Shintani, 2014).

\subsection{Roles of the teacher}

As mentioned above, TBLT is defined as a "learnerdriven education" (Van den Branden et al., 2009, p. 3 ) and "aims to develop learners' communicative competence by engaging them in meaning-focused communication through the performance of tasks" (Ellis \& Shintani, 2014, p. 135). Therefore, it is necessary for the teacher to shift his role from being a knowledge-provider to being a facilitator.

In addition, Van den Branden (2016) states that the teacher, in a TBLT perspective, should perform his role of a mediator. The term mediating in language education refers to the many ways in which the teacher intentionally intervenes into the learning process to bring about highest learning effectiveness for learners. In this respect, the teacher interactionally supports learners in different ways, depending on the needs of learners and certain phases of the lesson.

\subsection{From teacher cognition to teacher teaching practice}

Obviously, what language teachers do in the classroom is not fully inspired by the theoretical knowledge to which they are exposed through available proposed research-based findings because, according to the teachers' point of view, what the researchers do in the laboratory conditions is often too far from what actually happens in their real classroom practices (Borg, 2006; Van den Branden, 2009a). Markee (1997, p. 81) states that researchers "do little to promote change in language education because they do not address the real-life concerns of teachers". Similarly, Burns (1999, p.14) considers the researchers to be people who "know little - and understand less - about the day-to-day business of life in the language classroom". With regard to teachers, Borg (2006, p.7) states that teachers are not "mechanical implementers of external prescriptions". Instead, they are "active, thinkingdecision makers who make instructional choices by drawing on complex practically-oriented, personalized and context-sensitive networks of knowledge, thoughts and beliefs" (Borg, 2003, p. 81 ). Therefore, it is easy to understand why teachers prefer to consider their own ways in teaching. The teachers often modify tasks given by the syllabus designers to suit their own beliefs on what they think is best for their teaching and learners (Nunan, 2004; Van den Branden, 2006, 2016).

With regard to language education, a number of factors causing for the incongruence between 
teachers' espoused beliefs or what they think and teachers' beliefs-in-action or what they actually do (Borg, 2003) have been taken into consideration. Van den Branden (2006) mentioned contextual constraints such as time limits, lack of appropriate teaching aids, conflicting beliefs, and finally conflicts between beliefs and skills as key factors deciding teacher action in practical classrooms. Similarly, East (2012) states that contextual factors such as the influence of the type of school, expectations from the school authority, classroom critical episodes, and individual learner differences play a partial role contributing to shaping teacher cognition, and subsequent teacher action.

\subsection{Teacher training of TBLT}

Research into the field of teacher training of TBLT indicates that most language teachers, after being trained toward TBLT, show a certain lack of ability in integrating this method into their classroom practices (Adamson \& Davison, 2003; Carless, 2003; Littlewood, 2007; Barnard \& Nguyen, 2010) or they tend to be resistant to the training program because they realize that what they were trained for does not match perfectly with their current classroom conditions and the required curriculum (Peeters \& Van den Branden, 1992); and importantly, they cannot satisfy their learners' needs (Eisendrath, 2001).

In an attempt to find more evidence on the issue of teacher training of TBLT as well as to extend the research base on the potential of TBLT implementation in a Vietnamese context, this study, therefore, aims to examine how in-service teachers, who have been using traditional form-based teaching syllabuses for years actually implemented the insights from a one-shot training program on TBLT.

\section{THE STUDY}

This study aims to examine how Vietnamese English as a Foreign Language (EFL) in-service teachers implement the insights from a one-shot training program on TBLT in their classroom-based teaching practices. The study addresses the following research question:

To what extent do Vietnamese EFL teachers, who have been using a form-based teaching syllabus for years, implement the insights from a one-shot training program on TBLT into their teaching practices?

\subsection{Method}

\subsubsection{Participants}

Three EFL in-service teachers teaching at Can Tho university, Vietnam volunteered to participate. One of them was male and the others were female. Their age range was between twenty seven to thirty two years. They had all been teaching English at tertiary level for at least four years. Prior to this study, these teacher participants were said not to have any relevant knowledge or experience of TBLT. In addition, a teacher who is also known as an expert in the field of TBLT was invited to be the trainer for the program.

\subsubsection{Instrument}

A video-taped classroom observation was used for data collection. Observation is a valuable strategy in collecting reliable data for qualitative studies (Creswel, 2018). Borg (2006, p. 231) states that observation provides "a concrete descriptive basis in relation to what teachers know, think and believe". In this study, this method provided valuable data on what happened in the observed classrooms, especially in terms of teachers' performances and their implementation of insights they developed during the training.

It is noted that the teachers may feel uncomfortable, even stressful if they know that they are being videotaped. In order to minimise the effect of the camera on the behaviour of the participants, they (prior to the study) were carefully explained that the videotaping was only for research purposes. In addition, instead of having someone video-taping in the classroom, a camera was set on an automatic function and it was carefully put in a corner of the classroom. By doing this, it is needless to say strongly believed that the classroom activity was not distracted more than absolutely necessary.

\subsubsection{Data collection}

Prior to the study, the three teachers were given a training on TBLT by the trainer. During this training, the teachers were first informed about TBLT theoretically. They were given all kinds of TBLT-related materials, i.e., books, articles and so on for reading purposes. Next, the teachers were asked to participate in a one-shot training workshop which lasted for one day. The training primarily aimed at presenting basic pedagogical teaching principles of TBLT, including the role of the teacher. The trainer illustrated his/her ideas of what makes a perfect TBLT approach. Specific examples 
were also provided with the aim of facilitating a smooth transition from what the teachers learnt during the training session to their subsequent teaching practices.

Data were collected via a video-taped classroom observation activity, then coded and analysed according to the research aims. For data collection, the teachers were each asked to teach a reading lesson by TBLT.

For the teaching materials, four reading texts describing four famous destinations in Vietnam were chosen. Three task types including a true or false statement task, a multiple choice question task, and a comprehension question task were used. The choice of these task types was due to their popularity in the current teaching curriculum and also based on the assumption that students were familiar with them. In each task, five questions were used to test students' understanding of the reading texts. While teaching, the teachers were allowed to be flexible in using the given materials, and they were also encouraged to design extra tasks if they thought this would contribute to reaching the lesson goals.

\subsubsection{Data analysis}

To collect and analyse data, two steps were taken. In the first step, the videos of teachers' performances were analyzed, then coded into a common rating scheme by two judges independently. The scheme included two parts. Part 1 included four items related to TBLT principles, including meaningbased focus, learner-centered approach, holistic type of education, and form-focused activities. This part was used to evaluate how well the teachers adopted TBLT principles throughout the lesson. Part 2 included ten items which were about the roles of the teacher in TBLT. This part was used to measure how well the teachers adopted the role of the teacher in TBLT regarding a three-stage TBLT lesson. The coded data were then translated into numerical scores $(4=$ Very successful; $3=$ Successful; 2 = Unsuccessful; $1=$ Very unsuccessful) on the items in the rating scheme.

In the second step, the two judges double-checked the results together. All similar scores on particular items were taken into consideration for further analysis. Dealing with different scores, however, the two judges had to again review the videos of the teachers' performances and decide common scores.

\section{RESULTS}

On the whole, the results indicated that the teachers generally failed to apply TBLT $(\mathrm{M}=1.25)$ into their authentic classroom practices, both in terms of general teaching principles of TBLT $\left(\mathrm{M}_{\text {teacher } 1}=1.0\right.$, $\mathrm{M}_{\text {teacher2 }}=1.3, \mathrm{M}_{\text {teacher3 }}=1.3$, respectively) and the role of the teacher $\left(\mathrm{M}_{\text {teacher } 1}=1.2, \mathrm{M}_{\text {teacher } 2}=1.2\right.$, $\mathrm{M}_{\text {teacher3 }}=1.5$, respectively). In particular, the teachers seemed unable to adopt principles of meaning-focused, learner-centered and holistic education through all phases of the lesson. In addition, principles of form-focused activities in TBLT were not clearly embraced and adopted by the teachers. Regarding the role of the teacher in TBLT teaching, all teachers were struggling to take up their roles as mediators as indicated in TBLT (Van den Branden, 2016). For the sake of clarity, I will present the observed data of the teachers' actual performances in three phases of a TBLT lesson: pretask phase, during-task performance phase, and post-task phase.

\section{Pre-task phase}

The three teachers opened the lesson by introducing a communicative activity to enhance students' involvement and discussion. By doing so, the teachers assumed they could actively involve individual students in the lesson and also introduce necessary input, i.e., instructions, useful ideas, key vocabulary for them to perform the task in the next phase: task-performance.

The results showed that teachers 1 and 2 failed to adopt TBLT principles (meaning-based focus, learner-centered approach, and holistic type of education) and the role of the teacher in TBLT. However, compared to teachers 1 and 2, teacher 3 dealt with TBLT teaching more effectively.

More specifically, teacher 1 raised a list of openended questions related to the main theme of the lesson - tourism for classroom discussion. By doing this, the teacher aroused students' interests and involvement. However, the observed data indicated that teacher 1 did not provide students with any opportunities to work on the task in a free and communicative way. Rather, teacher 1 overcontrolled the interaction. (S)he stood in front of the whole class and invited individual students to make a contribution. (S)he also often interrupted the students while they were trying to give responses. Clearly, this type of instruction was inconsistent with TBLT teaching principles. 
In the same vein, teacher 2 also used open-ended questions to introduce the lesson. Unlike teacher 1, teacher 2 decided to use a group work activity to promote students' motivation as well as involve them in discussion. Teacher 2 divided the class into smaller groups and allowed each group to manage their own activity. On the whole, however, the results showed that teacher 2 failed to organize the activity in accordance with TBLT principles during the latter part of the phase. (S)he did not support and encourage the students effectively. For example, (s)he was unable to deal with students' problems associated with communication. Instead of acting as a conversational partner as proposed in TBLT, teacher 2 often dominated individual students/groups by giving her/his own ideas. In addition, teacher 2 did not maintain the pre-task activity long enough to help the students activate their interest, ideas, etc., into the lesson. Teacher 2 prematurely ended up the pre-task activity while the students were discussing with their peers. As a consequence, teacher 2 broke down the communication flow among students potentially reducing their enthusiasm and interest for the tasks involved.

In sharp contrast, teacher 3 adopted TBLT approach more effectively during the pre-task phase. Teacher 3 decided to use a drawing activity to start the lesson. To arouse students' interest and involvement, teacher 3 organized a group work activity and invited one volunteer in each group to come to the blackboard, together with the teacher, drawing a map of Vietnam. At the same time, other students were asked to do a similar task within their groups, followed by intensive discussion of the topic of the lesson - tourism. In this respect, teacher 3 directly involved students in the lesson and successfully offered them an opportunity to contribute their ideas. Moreover, students' prior knowledge and enthusiasm for the tasks was activated.

\section{During-task-performance phase}

The data illustrated that all teachers failed to adopt TBLT teaching principles and the role of the teacher in TBLT during this stage of the lesson. More specifically, they did not follow principles of meaning-based focus, learner-centered approach and holistic education. Moreover, they did not adopt the role of the teacher as mediator. It was observed that the teachers tended to over-emphasize lexicalgrammatical accuracy rather than taking students' achievement in task-based performance into consideration. They controlled too much and often interfered in students' activity, which is inconsistent with the principle of learner-centered approach.

Teacher 1, for instance, organized a group work activity to carry out the tasks but (s)he quickly turned it into a more lockstep-type activity for explicit teaching. This happened to teacher 2 also. On the whole, they strictly followed the given material and tried to solve the reading tasks in a traditional way, i.e., the teachers read the reading texts aloud to students for comprehension and invited individual students to answer each of the questions accurately. Teacher 3, compared to teachers 1 and 2, exploited the group work in a more effective manner. After putting students into groups, the teacher allowed them to work on the tasks in their own way. In this respect, teacher 3 gave students more opportunities to invest mental effort in the task and, at the same time, promote interactive skills through interacting with their peers. However, the results revealed that teacher 3 failed to adopt a truly supporting role while trying to help students solve difficulties in communication. Teacher 3 seemed unable to use strategic ways to support students. Very often, (s)he helped students who were in need by directly giving clear-cut answers to their problems. As such, the teacher limited the students' ability to solve the problems by themselves. Also, the teacher dominated students' activity thus hindering students' language development. Similar to teachers 1 and 2, teacher 3 put a strong focus on achieving accuracy although these teachers, prior to the study, had been trained in the view that the priority of teaching, under a TBLT perspective, must be placed on meaningful communication. In fact, instead of encouraging students to continue to perform the task, teacher 3 intentionally stopped the activity to move on to task correction. For the rest of the phase, teacher 3 was devoted all the time to teaching linguistic features and helping students achieve accuracy.

\section{Post-task phase}

In line with the during-task performance phase, all the three teachers did not implement the post-task phase properly. In other words, they did not offer students any opportunity to self-evaluate what they had learned. Also, the teachers did not summarize the learning output; and none of the teachers applied principles of form-focused instruction and feedback activities. Instead, they moved to the closing stage to end the lesson after they had finished correcting the reading tasks given in the material. In fact, the 
teachers controlled all of activities in the post-task phase regardless of what the students were learning and how they reacted to their learning.

\section{DISCUSSION}

The findings showed that the three teachers participating in this study largely failed to consistently apply principles of TBLT such as meaning-based focus, learner-centered instruction and holistic education throughout the lesson. Moreover, they failed to adopt the prescribed role of the teacher in TBLT. The teachers placed a strong focus on achieving linguistic accuracy and lexical items rather than targeting students' ability in communicative language use. In addition, the teachers seemed to lack confidence in allowing students to make decisions about their own learning progress but tended to over-control and interfere with students' activities (Kam, 2004). They also divided the language into discrete units for explicit teaching. In the same vein, the results indicated that the teachers were unable to apply principles of formfocused activities and teacher-led activities in TBLT, clearly observed in the post-task phase or when the teachers had to deal with students' difficulties with linguistic rules. The teachers, in general, preferred either to explain vocabulary and individual linguistic features to the students explicitly or to keep going on with the lesson without considering the problems that the students were facing.

From these observed data, it can be concluded that the one-shot training program which took the shape of theory-based and outside-the-classroom type of training in this study was ineffective (also see Van den Branden, 2006). Evidently, this training program did not sufficiently help the teachers to make any crucial changes in their classroom-based approach. One explanation may be that they were reluctant to adopt task-based principles. In view of the fact that as many as $75 \%$ of all innovations in education fail in the long term (Markee, 1997) mainly because most adopters, who are trained to implement those innovations, are not suitably supported or are not convinced that the new approach will be worthwhile or more effective. Rather, they rely on their collective and individual experience (Cochran-Smith \& Lytle, 1993) or they prefer to modify the innovation in a way they think is best for their teaching methods and for their students (Van den Branden, 2016).

There may be several reasons why teachers are reluctant to implement a given innovation. Firstly, they may not fully grasp the basic principles of the innovation or lack the basic knowledge or background to do so. Secondly, the principles may be at odds with teachers' own beliefs on what constitutes effective teaching for their particular group of learners. Thirdly, even if they are convinced that the innovation may be effective and understand what it is about, they may lack the practical skills to put it into practice; or lack the confidence to implement these procedures. With a complex innovation like TBLT that touches upon a great number of aspects of language teaching, the above-mentioned explanations may actually be at play at the same time and reinforce each other (Van den Branden, 2009a, 2016).

Therefore, it is suggested that a training program on TBLT offered to teachers in Vietnam in the future should not be too ambitious, but work in a more gradual way (Carless, 1997). It is important to note that it takes a lot of time for the teacher to become fully convinced of the potential of TBLT as a powerful tool in language education, and to transfer his/her theoretical insights of TBLT into practical teaching practices (Van den Branden, 2006). In this respect, it is reasonable to suggest that educational leaders need to think of a long-term trajectory of professional development for teachers toward TBLT (Van den Branden, 2006; East, 2012). In fact, research into the factors nurturing teachers' professional development is well worth considering. For instance, in her study, Drijkoingen (2017) points out, in order to stimulate professional development for teachers, four aspects of growth needed to be taken into account when designing trajectories of teacher development. These are collaboration, reflection, experimenting or trying out things in practices, and finally gaining input or insights.

\section{CONCLUSIONS}

The results indicated that in-service teachers failed to apply TBLT into their teaching practices after receiving a one-shot training about it. Although they made clear attempts to comply with the principles of meaning-focused, holistic and learner-centered instruction in TBLT, they were unsuccessful in achieving them. In addition, the teachers were not able to implement the principles of form-based focus properly. Regarding the role of the teacher in TBLT, these teachers had difficulty in systematically adopting the role as mediator. Among different reasons discussed, i.e., the heavy influence of the traditional teaching methods and negative effects caused by current language 
teaching policies such as form-based teaching syllabuses, assessment and materials, the ineffectiveness of the one-shot training program on TBLT that we conducted was raised of the most plausible explanation. It is, therefore, implied that such a training model or similar ones should not be encouraged. Obviously, if the educational leaders want to implement TBLT sucessfully, it is first and foremost necessary for them to think of another sufficient and sustainable training program for the teachers because it is the teachers who are key agents of any pedagogical innovations. Also, the teachers need to be well supported with regard to teaching skills and teaching experience. Indeed, this could be fostered in many ways such as, for instance, sharing or co-teaching activities among teachers.

It is important to indicate that limitations associated with this study are inevitable. Firstly, the number of participants in this study is too small to draw any general conclusions. In fact, only three EFL inservice teachers at tertiary level were involved. It is, therefore, limited in terms of generalisation to other teacher populations and also other EFL teaching contexts such as primary and secondary levels. Secondly, the one-shot training session for teachers on TBLT, which was limited to one day training, is too short for both the trainer and trainees to take advantage of it. Dealing with trainees' teaching performances in their classroom practices, a 90minute lesson is not long enough to evaluate the effect of the experiment efficiently. Clearly, if the current study had been conducted for a longer treatment time, its results could have been better evaluated. Therefore, it is implicated that any generalisation of the results from this study should be carefully considered.

Due to the time limitation in which both the training and the experiment took place, the results were disappointing. In this respect, it is suggested for future research that a longitudinal study should be conducted. In addition, a replication of the current study should be conducted with more participants from other contexts such as primary and secondary levels. It is noted that the current study is an attempt to examine the teachers' application of TBLT into their teaching practice but not to investigate their beliefs about the training program on TBLT. Therefore, further research exploring EFL inservice teachers' beliefs about a training program on TBLT is worth considering.

\section{REFERENCES}

Adamson, B., \& Davison, C., 2003. Innovation in English language teaching in Hong Kong primary schools: One step forward, two steps sideways? Prospect, 18(1): 27-41.

Bachman, L. \& Palmer, A, 1996. Language Testing in Practice. Oxford: Oxford University Press.

Barnard, R., \& Nguyen, V. G., 2010. Task-Based Language Teaching: A Vietnamese Case Study Using Narrative Frames to Elicit Teachers' Beliefs. Language Education in Asia, 1(1): 77-86.

Breen, M, 1987. Learner contributions to task design. In C. Candlin \& D. Murphy (Eds.), Language Learning Tasks (pp. 23-46). London: Prentice Hall.

Borg, S., 2003. Teacher cognition in language teaching: A review of research on what language teachers think, know, believe, and do. Language Teaching, 36: 81-109.

Borg, S., 2006. Teacher cognition and language education. London, UK: Continuum.

Bygate, M., Skehan, P. \& Swain, M. (Eds.). 2001. Researching pedagogical tasks: Second language learning, teaching and testing. Harlow: Longman.

Burns, A., 1999. Collaborative action research for English language teachers. Cambridge: Cambridge University Press.

Canh, L., 2011. Form-focused instruction: A case study of Vietnamese teachers' beliefs and practices. Unpublished Ph.D. Thesis: The University of Waikato, New Zealand.

Carless, D., 1997. Managing systemic curriculum change: A critical analysis of Hong Kong's targetoriented curriculum initiative. International Review of Education, 43(4), 349-366.

Carless, D., 2003. Factors in the implementation of taskbased teaching in primary schools. System, 31(4): 485-500.

Caroll, J, 1993. Human Cognitive Abilities. New York: Cambridge University Press.

Creswell, W. J., \& Creswell, D. J., 2018. Research design: qualitative, quantitative, and mixed methods approaches. SAGE publications India Pvt. Ltd.

Drijkoningen, J., 2017. Wheels of change: Insights into the professional development of teachers of Dutch as a second language. Unpublished Ph.D. Thesis: KU Leuven, Belgium.

East, M., 2012. Task-based language teaching from the teachers' perspective: Insights from New Zealand. Amsterdam/Philadelphia, PA: John Benjamins.

Eisendrath, H., 2001. Evaluatie van de lerarenopleiding in Vlaanderen 2000-2001. Brussels: Vrije Universiteit Brussel.

Ellis, R., 2003. Task-Based Language Learning and Teaching. Oxford: Oxford University Press. 
Ellis. R., 2009. Task-based language teaching: Sorting out the misunderstandings. International Journal of Applied Linguistics, 19(3), 221-246.

Ellis, R., \& Shintani, N., 2014. Exploring Language Pedagogy through Second Language Acquisition Research. London, England: Routledge.

Kam, H. W., 2004. English Language Teaching in East Asia Today: An Overview. Asia Pacific Journal of Education, 22(2), 1-22.

Littlewood, W., 2007. Communicative and task-based language teaching in East Asian classrooms. Lang. Teach, 40, 243-249.

Long, M, 1985. A role for instruction in second language acquisition: Task-based language teaching. In: K. Hylstenstam \& M. Pienemann (Eds.). Modelling and Assessing Second Language Acquisition (pp. 77-79). Clevedon: Multilingual Matterns.

Long, M., 2015. Second Language Acquisition and Task-Based Language Teaching. Sussex, UK: Wiley Blackwell.

Markee, N., 1997. Second language acquisition research: A resource for changing teachers' professional cultures? The Modern Language Journal, 81(1): 80-93.

Ministry of Education and Training [MoET], 2006. Chuong trinh giao duc pho thong: Mon Tieng Anh [English curriculum for the secondary school]. Hanoi, Vietnam: Education Publishing House.

Norris, J. M., 2016. Current Uses for Task-Based Language Assessment. Annual Review of Applied Linguistics, 36: 230-244.
Nunan, D, 1989. Designing tasks for the communicative classroom. Cambridge: Cambridge University Press.

Nunan, D., 2004. Task-based Language Teaching. Cambridge, England: Cambridge University Press.

Peeters, K., \& Van den Branden, K., 1992. Nascholing nascholing! Naar een professionalisering van de nascholing voor leraren. Leuven: Garant.

Richards, J., Platt, J. \& Weber, H, 1985. Longman Dictionary of Applied Linguistics. London: Longman.

Skehan, P., 1996. A framework for the implementation of task-based instruction. Applied Linguistics, 17(1), 38-62.

Skehan, P., 2003. Task-based instruction. Language teaching, 36(1), 1-14.

Thornbury, S., 1999. How to teach grammar. Harlow: Longman.

Van den Branden, K., 2006. Task-based language education: From theory to practice. Cambridge: Cambridge University Press.

Van den Branden, K., 2009a. Diffusion and Implementation of Innovations. In: Long, M. H., \& Doughty, C. J. (Eds.). The Handbook of Language Teaching, 559672. Blackwell Publisher.

Van den Branden, K., 2016. Task-based language teaching. In G. Hall (Eds.), The Routledge Handbook of English Language Teaching, 238-252. New York: Routledge.

Van den Branden, K., Bygate, M., \& Norris, J., 2009. Task-based language teaching: A reader. Amsterdam: John Benjamins. 